3. Гуцульські говірки : короткий словник / уклад. : Г. Гузар, Я. Закревська, У. Едлінська, В. Зеленчук, Н. Хобзей. Львів, 1997. 232 с.

4. Дехтярьова О.В. Лексичні запозичення в компонентному складі діалектних фрразеологізмів (на матеріалі художніх творів західноукраїнських письменників кінця XIX - початку XX століття). Філологічні студії. Структура і семантика мовних одиниць. 2013. Вип. 9 (2). С. 23-29.

5. Дмитренко О., Полуніна Ю. Німецькі лексичні запозичення в українському розмовному дискурсі. Імідж сучасного педагога. 2019. № 2 (191). С. 63-67.

6. Кузь Г.Т. Лексичні запозичення в діалектній фразеології говірок Чернівецької області: Діахронічний аспект. Studia z Filologii Polskiej i Słowiańskiej. 2019. № 54. URL: https://ispan.waw.pl/journals/index.php/ sfps/article/view/sfps.1774 (дата звернення: 06.05.2021)

7. Лесів М. Основні характерні особливості системи лемківських говірок. Studia Methodologica. 2009. Вип. 27. С. 15-29.

8. Лопушанський В.М., Пиц Т.Б. Німецькомовні лексичні запозичення у південно-західних говорах України : навчальний посібник. Дрогобич : Посвіт, 2011. 122 с.

9. Лопушанський В.М., Пиц Т.Б. Німецькі лексичні запозичення у бойківському говорі: кількісний, тематичний і соціолінгвістичний аспект. Мовні і концептуальні картини світу. 2013. Вип. 46 (2). С. 385-399.

10. Нечаєва Н. Запозичення 3 німецької мови в буковинських говірках. Науковий вісник Східноєвропейського національного університету імені Лесі Українки: Серія «Філологічні науки: Мовознавство». 2014. № 2. С. 98-102.

11. Онишкевич М.Й. Словник бойківських говірок : у 2 ч. ; АН УРСР, Ін-т мовознавства ім. О.О. Потебні. Київ : Наук. думка, 1984. Ч. 1. 494 с.

12. Пиц Т.Б. Посередництво німецької мови у запозиченні іншомовних лексем південно-західними говорами української мови. Сучасні дослідження з іноземної філології. 2011. № 9. С. 374-379.

13. Пиц Т. До історії дослідження німецьких запозичених слів в українській мові. Українська мова. 2013. № 2. C. 84-98.

14. Пиц Т. Дослідження німецьких лексичних запозичень в українській мові у німецькомовних країнах. Актуальні питання гуманітарних наук. 2012. С. 274-280.

15. Підкуймуха Л.М. Лексичні запозичення в батярському жаргоні міжвоєнного Львова. Компаративні дослідження слов'янських мов і літератур. 2013. Вип. 22. С. 139-149.

UDC 378.147:811

DOI https://doi.org/10.32782/tps2663-4880/2021.16.12

\title{
TEACHING FOREIGN LANGUAGES FOR PROFESSIONAL PURPOSES TO THE APPLICANTS OF HIGHER NON-LINGUISTIC EDUCATION
}

\section{ВИКЛАДАННЯ ІНОЗЕМНОЇ МОВИ ПРОФЕСІЙНОГО СПРЯМУВАННЯ ЗДОБУВАЧАМ ВИЩОЇ НЕМОВНОЇ ОСВІТИ}

\author{
Holubova H.V., \\ orcid.org/0000-0003-1420-0591 \\ Candidate of Pedagogical Sciences, \\ Senior Lecturer at the Department of Ukrainian and Foreign Languages \\ Odesa State Agrarian University
}

\begin{abstract}
The article is devoted to the analysis on the issue of professionally oriented foreign language teaching of the applicants of higher non-linguistic education. It is determined that the increasing role of foreign languages in modern world significantly changes both the requirements for the proficiency of the future non-linguistic specialists' and for their level of preparedness for professional activities, which is entirely related to their competitiveness in the labor market. In this regard, professionally oriented foreign language training is undoubtedly recognized as a priority in the renewal of modern higher education. The aim of the article is to consider the peculiarities of teaching professionally-oriented foreign language to the applicants of higher education in non-linguistic specialties. During the theoretical and methodological analysis of the scientific fund on the given problem it was found out that the term "professionally oriented training" is used to denote the process of teaching a foreign language in a non-linguistic higher educational institution, focused on reading literature on specialty, studying the professional vocabulary and terminology, as well as communicating in the field of professional activity. It is emphasized that educational process should be formed as close as possible to the real communicative situation. The features of foreign
\end{abstract}


language teaching in non-linguistic higher educational institutions are characterized. During the study it was determined that the content of foreign language teaching should include: the areas of communication, topics and situations, language actions and speech material, which take into account the professional orientation of applicants for non-linguistic higher education; language material (phonetic, lexical, grammatical, orphographic), rules of its layout and skills of operating; a set of special skills that characterize the level of practical mastery of a foreign language as a means of generalization. The essence and the content of the construct "communicative orientation" are considered.

Key words: communication, communicative orientation of education, active teaching methods, non-linguistic education, professionally oriented education.

Статтю присвячено аналізу проблеми викладання іноземної мови професійного спрямування здобувачам вищої немовної освіти. З'ясовано, що підвищення ролі іноземних мов у сучасному світі суттєво змінює вимоги як до їх оволодіння, так і до рівня підготовленості майбутніх фахівців-немовників до професійної діяльності, що цілком пов'язано з їх конкурентоспроможністю на ринку праці. У зв'язку з цим не викликає сумніву, що професійноорієнтоване навчання іноземної мови визнається пріоритетним напрямом в оновленні сучасної вищої освіти. Метою статті є розгляд особливостей викладання професійно-орієнтованої іноземної мови здобувачам вищої освіти немовних спеціальностей. Під час теоретико-методологічного аналізу наукового фонду з означеної проблематики було встановлено, що термін «професійно-орієнтоване навчання» вживається для позначення процесу викладання іноземної мови в немовному закладі вищої освіти, орієнтованої на читання літератури за фахом, вивчення професійної лексики та термінології, а також на спілкування у сфері професійної діяльності. Наголошено, що навчальний процес повинен будуватися максимально наближено до реальної комунікативної ситуації. Схарактеризовано особливості навчання іноземної мови у немовних закладах вищої освіти. Було встановлено, що у зміст навчання іноземної мови професійного спрямування слід включати: сфери комунікативної діяльності, теми та ситуації, мовні дії та мовленнєвий матеріал, які враховують професійну специфріку здобувачів немовної вищої освіти; мовний матеріал (фонетичний, лексичний, граматичний, орфографічний); комплекс спеціальних умінь, що характеризують рівень практичного оволодіння іноземною мовою як засобом узагальнення. Розглянуто сутність і змістове наповнення конструкту «комунікативна спрямованість».

Ключові слова: комунікація, комунікативна спрямованість навчання, активні методи навчання, немовна освіта, професійно орієнтоване навчання.

The statement of the problem. In the modern conditions of education development there is an increase in the requirements for the future specialists, revealed not only in a demand for a high level of knowledge and skills on the specialty, but also high possession of a foreign language. At the same time, the role of foreign languages as an important means of intercultural communication is increasing, and the requirements for proficiency in a foreign language are significantly changing. Learning a foreign language becomes an indispensable component of education. Thus, language knowledge is not only an indicator of individual's high cultural level, but also a significant contribution to his / her successful professional activity.

The implementation of the Bologna system into the educational process, the developing of international relationships of Ukraine specifies the increasing importance of learning foreign languages by the specialists of various fields. In view of that, the problem of forming the foreign language communicative competence of the students of non-linguistic specialties has become especially relevant. This determines the attribution of foreign language training of the students of non-linguistic specialties to the most important components of higher education.

The use of a foreign language in later life and work becomes the priority goal of its mastering. The objective reality of today is the widespread development of international contacts with foreign countries representatives. Language is an important means of intercultural communication and the access to the world culture. Foreign language knowledge allows the higher education applicants to be more competitive in the labor market, to establish relations with international colleagues, to participate in international training and exchange programs.

Professional-oriented foreign language teaching is currently recognized as a priority in the renewal of education. Professional orientation should be the main peculiarity of foreign language teaching in non-linguistic higher educational institutions, because it is based on taking into account the needs of future specialists since the main task of foreign language training is to teach professionally oriented communication.

Foreign language communication becomes an essential component of the specialists' professional activity. One of the features of studying the language of professional orientation is that it should be as close as possible to the future specialist's real professional activity. The term "professionally oriented training" is used to denote the process of teaching a foreign language in a non-linguistic university, focused on reading vocational subjects literature, professional vocabulary and terminology studying, and recently - on the communication in the field of professional activity as well. Thus, vocational training is considered the one that is based on taking into account the students' needs for learning a foreign language, caused by specifics of the future profession or specialty. Despite considerable attention 
to this problem, the latter needs a follow-up-study regarding difficult, sometimes contradictory tasks and conditions, such as reducing classroom hours for learning a foreign language in non-linguistic higher educational institutions and increasing requirements for non-linguistic professionals for high-level possession of professionally oriented foreign language.

Analysis of recent research and publications. The analysis of scientific and pedagogical sources revealed that there are many methodological areas of teaching a foreign language in non-linguistic universities. Note the following areas of research on this problem:

- methodological bases for composing the educational process in educational institutions were studied by N. Alexandrov, T. Ilyina, P. Pidkasisty, et al.;

- V. Humboldt, O. Leontiev, L. Palamar, V. Skalkin, L. Vygotsky, I. Zimnyaya, et al. devoted their research to the theory of speech activity and communication;

- the problem of foreign language competence and its formation was studied by such scientists as: A. Andrienko, E. Bibikova, N. Chomsky; R. Ellis, V. Hnatkevych, O. Izmailova, N. Katrych, M. Kenel, N. Kopylova, I. Nation, Y. Passov, S. Shatilov, N. Schmitt, Yu. Solodovnikova, O. Tarnopolsky, and others.

- the communicative approach to foreign language teaching was studied by L. Birkun, S. Brumfit, T. Duchenko, L. Holubenko, R. Johnson, H. Kitaygorodskaya, T. Levchenko, J. Manby, E. Passov, et al.

- I. Berman, N. Borysko, V. Buchbinder, I. Hirenko, H. Hryniuk, A. Koval, S. Kozak, R. Martynova, N. Mykytenko and others devoted their research to the content of teaching a foreign language in professional communication.

- the problem of forming the foreign language communicative competence of the non-linguistuc specialties students was studied by such scientists, as A. Astaduryan, L. Borozenets, M. Evdokimova, O. Fadeikina, N. Havrilenko, O. Hrigorenko, E. Komarova, N. Kucherenko, T. Luchkina, Y. Maslova, O. Metelkina, B. Zykova.

Good knowledge of a foreign language is an important prerequisite for personal, cultural, professional and economic contacts, the process of mastering a foreign language is considered as the student's personal development [3, p. 75].

The aim of the article is to consider the peculiarities of teaching professionally-oriented foreign language to the students of non-linguistic specialties.

Presentation of the main research material. The main purpose of teaching a foreign language in higher educational institution is first of all the formation of professionally oriented competence. In modern conditions of education reforming, society needs competitive high-level professionals with nonstandard thinking, being able to master information from the foreign sources, which will allow to share experiences in a foreign language environment, gaining new knowledge for the benefit of their own country. Therefore, teaching a foreign language to the future specialists should bring the main profession as close as possible to the use of a foreign language, and the learning process itself should be practically oriented. Thus, the purpose of learning foreign languages is not a language system, but foreign language speech activity, not in itself, but as a means of intercultural interaction.

Teaching a foreign language in a non-linguistic university is understood as teaching intercultural communication, indissolubly connected to the use of modern methods. Today, the question arises how to learn a foreign language and what material to teach in order to meet the goals and requirements of vocational training.

There is a tendency for the process of teaching English communication to be more student-centered and less time consuming. Language learning should ideally be based on a naturally acquired language abilities, being enriched through the development of literacy into an instrument for abstract thought and the acquiring of academic knowledge [13, p. 178].

N. Galskova considers the foreign language to be the effective means of professional and social orientation in a non-linguistic university. Rendering a foreign language as a means of forming the future specialist's professional orientation, the researcher notes that while studying the professionally-oriented language material a two-way connection is established between the student's desire to acquire special knowledge and the success of language mastering [2, p. 4]. According to the author, realization of this potential is promoted by the following conditions: clear formulation of the purposes and social and professional orientation of foreign language speech activity, students' satisfaction while solving individual tasks and the formation of their ability to be creative in solving those tasks. Therefore, an important role is played by a favorable psychological climate in the learning collective.

Given the consideration that communicative competence formation is the primary goal and final result of learning a foreign language in higher educational institution, there is a question of improving teaching methods and means of mastering the skills necessary 
to acquire the communicative competence in the field of professional communication in a foreign language. It is advisable to use universal methods of teaching a foreign language, which will enable the achieving of a higher level of training by integrating language and professional spheres.

Traditionally, universities use such methods of teaching a foreign language for students of nonlinguistic specialties, which are based on the translation of specialized educational texts, terminology and grammar learning. This technique helps to develop the skills of reading, text interpretation, enables mastering of the professional terminology, and at the same time has a negative effect on students' communicative abilities. Therefore, the selection and application of rational teaching methods in foreign language classes is the teacher's primary task, as well as a creative approach to them. A. Kuzminsky in his scientific work proves that the use of teaching methods requires teacher's creative approach [8, p. 159-160].

The principle of professional orientation of educational material in the process of teaching a foreign language in non-linguistic higher educational institution was substantiated by the team of authors (P. Obraztsov and others) who emphasize that studying a foreign language should not be an end in itself, but a means to achieve the goal of increasing the level of education, erudition within their specialty. The specifics of profiling specialties should be taken into account in the following areas: studying of vocabulary-minimum on the specialty, working on special texts, studying of special topics for the oral speech development, creating manuals for activating grammatical and lexical material [9]. In addition to the ability of communicating on household topics, specialists need capability skills on professionally oriented translation in the field of study. However, conducting a spontaneous conversation on professional topics with native speakers verbally or in writing involves a high level of active posession of the foreign language [7, p. 52].

Teaching a foreign language in non-linguistic universities can be characterized by the following pecularities. Firstly, it is the short term of a foreign language course for students of non-linguistic specialties, which does not allow complete covering of the full range of professionally oriented and basic educational material. Secondly, the accessibility and comprehensibility of educational material needs special attention. This obliges the teacher to follow the sequence of learning a foreign language, starting with basic general knowledge of a foreign language and gradually moving to specialized material, which is already known to the students from the professional disciplines; to increase the motivation of learning, to develop the ability of learning a foreign language, to correctly select certain methods and techniques of the learning process (J. Berman).

Another particularly important task of modern methods of teaching foreign languages in non-linguistic universities, given the need of the modern world for highly qualified specialists who can speak a foreign language at a sufficient level, is to increase the efficiency of the educational process within a limited number of classroom-based hours. In the conditions of the most concise course of learning a foreign language (one lesson per week) it is extremely difficult to provide the student with the level of an independent or advanced language user [4].

$\mathrm{N}$. Volkova identified the criteria for selecting qualitative methods of teaching a foreign language, namely: the student being the main figure in the learning process; creating comfortable and interesting situations, which aim to intensify the student's activity; encouraging students to work during the lesson through their emotions and feelings; stimulating the development of students' language skills; using various forms of work during the lesson - individual, group, collective [1, p. 320].

Today, during foreign language classes, different methods, highlighting the communicative one, should be used for improving the skills and knowledge of the students of non-philological specialties.

For setting the students' progress goals and for identifying the knowledge gaps it is important to know the students' needs and their current ability level. For that matter the needs analysis can be used so that each semester moves the students a step closer to their target level in each of the language learning skills (reading, writing, listening and speaking) [12].

Communicative orientation of education is a prerequisite for success in the students' practical mastering of a foreign language. The learning process should be formed as close as possible to the real communicative situation. Therefore, the atmosphere of collective communication, organized on the basis of communicative situations, is important. Foreign language teaching is built adequately to the real process of speech communication, i.e. the learning process is a model of the process of speech communication. Convergence of the learning process and that of communication on such important parameters as communicative-motivated speech behavior of teachers and students, as well as the subjectivity of the communication process is provided by careful selection of communicative-speech intentions, topics, situations that reflect students' interests 
and needs. Such situations stimulate the students to communicatively motivated implementation of speech actions, whereas communication in such situations allows them to consciously learn the foreign language material [10].

The principle of communicative orientation of learning means that the educational process in a foreign language teaching should be organized, directed and implemented so that, as a result of learning, students acquire the minimum of skills and abilities to use the foreign language as a means of communication within the topics suggested by the program. To achieve this purpose, first of all, it is important to organize practical activities in the language being studied, from the standpoint of oral foreign language speech and while reading a foreign language text. Therefore, it is advisable to perform the sufficient guantity of speech (in other words, communicative) exercises that contribute to the formation of practical skills and abilities in the main types of speech activity. Thus, speech exercises are being the determining factor in the practical posession of a foreign language. In its turn, the communicative orientation means that during the assimilation of speech material (phonetics, vocabulary, grammar) the obligatory culminating step is the demonstration of the use of speech material in the actual foreign language communication $[5$, p. 78$]$.

According to N. Galskova, the content of foreign language teaching should include:

- spheres of communication, topics and situations, language actions and speech material, which take into account students' professional orientation;

- language material (phonetic, lexical, grammatical, orthographic), the rules of its layout and operating skills;

- a set of special linguistic (language) skills that characterize the level of practical mastery of a foreign language as a means of generalization, in intercultural situations as well;

- system of knowledge of national and cultural features and realities of the country of the language studied [2, p. 17].

Recently, along with traditional methods of teaching a foreign language, the innovative ones have become widespread, among which a significant place is occupied by active teaching methods, notice that their main purpose is also the formation of students' foreign language communicative competence.

Based on the research of I. Zymnya, S. Nikolaeva, E. Passov, it was established that, along with traditional methods of the foreign language teaching, the innovative ones have become widespread, among which the active teaching methods occupy a significant place. The latter are also aimed at students' for- eign language communicative competence formation. The use of active methods in the practice of teaching a foreign language to the students of non-linfuistic specialties contributes not only to the assimilation of the language knowledge by the students, but also improves professionally-oriented communication, as those methods stimulate students' cognitive activity, being based mainly on a dialogue, which involves a free views exchange on the ways of solving a certain problem and are characterized by a high level of students' activity [11, p. 297].

Active teaching methods can be used at different stages of learning a foreign language. The use of active foreign language teaching methods provides the assimilation of material by the students most fully and for their own benefit, i.e. they are aware of the importance of educational material and consider how to apply the knowledge in real life situations or further learning [11, p. 298].

The most common are such active methods as: imitative (usually involve training in professional skills and skills related to the modelling of professional activities, in other words, imitate both the situation and the professional activity itself); game, roleplaying (role game, business game); non-game (involve the analysis of specific situations); solution of situational problems; exercises, implementation of individual tasks [6, p. 5].

While learning a foreign language, students perform various types of work with books on their future specialty: receive the necessary information, process the content of reading material, master dialogic and coherent monologue speech at the level of both self-prepared and unprepared utterances, translate or review the necessary material, practice in developing the speech skills within a certain specialization.

Students must also posess the skills for verbal and written translation from their native language into a foreign language and vice versa; concisely and accurately express opinions in foreign and native languages; have knowledge on culture of the studied language country; use dictionaries and reference material when translating.

Thus, the effective formation of the foreign language communicative competence of the nonlinguistic specialties students and their development as competent and competitive professionals depends on the correctly chosen methods of foreign language teaching.

Conclusions. The analysis of the theoretical foundations on the problem of teaching professionally oriented foreign language to the applicants of higher non-linguistic education does not cover all the aspects of this problem. The need for further 
formation of the speech personality of higher education applicants during their professional development in higher non-linguistic educational institutions was substantiated. That is why we see the prospect for further research in the justification and implementa- tion into educational process of the relevant foreign languages teaching methods, which will contribute to the formation of foreign language communicative competence of the higher education applicants at non-linguistic specialties.

\title{
REFERENCES:
}

1. Волкова Н.П. Педагогіка : навчальний посібник. Київ : Академвидав, 2007. 616 с.

2. Гальскова Н.Д. Современная методика обучения иностранному языку : пособие. Москва : АРКТИГлосса, 2000. 165 с.

3. Зимняя И.А. Педагогическая психология. Москва : Логос, 2001. С. 384.

4. Золотова С.Г., Міхно С.В. Розвиток навичок іншомовної комунікації студентів та аспірантів. Вісник Глухівського національного педагогічного університету імені Олександра Довженка. 2017. Вип. 34. C. 93-101.

5. Капітан Т.А. Комунікативна спрямованість освітнього процесу в навчанні іноземних мов. Наукові записки. Серія : Педагогічні науки. Вип. 192. Кропивницький : РВВ ЦДПУ ім. В. Винниченка, 2021. С. 77-80.

6. Коваль Т.І. Інтерактивні технології навчання іноземних мов у вищих навчальних закладах. Інфрормаційні технології і засоби навчання. 2011. № 6 (26).

7. Коломієць С.С. Навчання спеціалістів професійно-орієнтованого спілкування із зарубіжними партнерами (на матеріалі англійської мови) : дис. ... канд. пед. наук : 13.00.02. Київ, 1993. 162 с.

8. Кузьмінський А.І., Омеляненко В.Л. Педагогіка : підручник. Київ : Знання-Прес, 2008. 447 с.

9. Образцов П.И., Ахулкова А.И., Черниченко О.Ф. Проектирование и конструирование профессиональноориентированной технологии обучения. Орел, 2005. 61 с.

10. Стойко С.В. Реалізація комунікативного підходу в навчанні іноземних мов. Вісник Чернігівського національного педагогічного університету. 2011. Вип. 85. Серія : Педагогічні науки. С. 220-223.

11. Сумцова О.В. Формирование иноязычной коммуникативной компетенции студентов технических вузов при использовании активных методов обучения иностранному языку. Молодой ученый. 2012. № 2. C. $297-298$.

12. Balatska L.P., Vyslobodska I.M. Needs analysis in teaching English for specific purposes. Вчені записки Таврійського національного університету імені В.І. Вернадського. Серія : Філологія. Соціальні комунікації. 2020. T. 31 (70). № 1. Ч. 2. C. 16-19.

13. Zapotichna R.A., Romanyuk O.M. Alternative methods of teaching foreign languages at higher education establishments with specific training condition. Закарпатські філологічні студії. 2020. Вип. 13. Т. 1. С. 177-180.

\section{STYLISTIC ASPECT OF THE QUEEN ELIZABETH II CHRISTMAS 2020 MESSAGE (12.25.2020)}

\section{СТИЛІСТИЧНИЙ АСПЕКТ РІЗДВЯНОГО ПОСЛАННЯ КОРОЛЕВИ ЄЛИЗАВЕТИ ІІ (25.12.2020)}

\author{
Humeniuk N.H., \\ orcid.org/ 0000-0002-2275-1396 \\ Candidate of Philological Sciences, \\ Associate Professor at the Department of English Philology and Translation \\ Borys Grinchenko Kyiv University
}

The following work is devoted to the problems of the Expressive means and Stylistic devices usage within the Queen Elisabeth II Christmas 2020 discourse, the 25-th of December, 2020. The annual Queen Elisabeth II Christmas message is defined in the given work as the Queen Elisabeth II Christmas discourse with the features of argumentative, declarative and the appealing to act discourses with the pragma-communicative purposes to congratulate the inhabitants of the UK and the Commonwealth realm on the Jesus Christ Birth occasion, to analyze and make conclusions of the year passing over, to draw the plans and guide lines of the forthcoming year. It is pointed out, that traditional in nature Queen Elisabeth II 